UDC: 332.142 .6

JEL Classification O10, O21, O29

\title{
SCIENTIFIC AND METHODOLOGICAL APPROACH TO THE EVALUATION OF THE POTENTIAL OF ECONOMIC ACTIVITIES TYPES
}

\author{
Oleksandra Karintseva, PhD in Economics. \\ Sumy State University
}

\begin{abstract}
(C) Karintseva O., 2018.
Стаття отримана редакиією 18.02.2018 p.
\end{abstract}

Problem statement. The evaluation of the highest possible level, which economic agents can achieve, certainly acts as a basis of research aimed at intensifying the process of a state development. A quantitative measurement of potential of types of economic activities creates an informative base for effective management decisions making about the investment focus of resources and vectors of state support for economy at the macro level, and on further business development and life cycle stages of the company at the micro level. At the same time, ignoring the environmental component of functioning business entities remains a significant problem of an adequate evaluation of the potential of types of economic activities. Thus, increasing the rate of production, such as manufacturing or mining industry due to failure to comply with the standards of environmental protection destroys the standards of living and development of the population in the given territory. The result of such achievement of the maximum possible performance of enterprises will lead to the dissolution of production after a certain period.

Thus, the activation of functioning of economic agents should occur in parallel with the compliance with environmental protection requirements, which provides an opportunity to develop any type of economic activity. So, the scientific and methodological support for assessing the potential of types of economic activities in Ukraine surely should consider the environmental component of economic development.

Analysis of recent researches and publications. A considerable number of foreign and domestic scientific works have been devoted to the study of the methodological basis for assessing the potential of various aspects of industrial enterprises. Thus, the peculiarities of innovative potential estimation are investigated in the works by such scientists, as: Hrynov A.V. [5], Martyusheva L.S. [13], Rossokha V.V. [15], Smirnova H.A. [17]. In turn, the mechanism for assessing the labor potential is revealed in the works by Varnalii Z.S. [3], Hrynova V.M. [6], Dehtiarenko I.V. [7], Dyblenko V.I. [8], Ilchuk O.O. [9]. The following scientists fix their attention on the appraisal of competitiveness potential: Amosov O.Yu. [1], Balatskyi O.F. [2], Voronkova A.E. [4], Fedonin O.S. [18], Khomiakov V.I. [19]. The development of mathematical tools for estimating various types of potential occurs thanks to works: Kaliuzhna N.H. [10], Kostenko O.P. [11], Kuzmenko O.V. [12], and others.

Unsolved parts of a common problem. The investigation of existing scientific and practical sources allows us to state that domestic and foreign scientists mostly take notice of assessing the potential of a specific line of business entity or the component of its business process. At the same time, an insufficient attention is paid to indicators that characterize the destructive impact of economic agents' activities on the environment, which eventually influences the estimated component of the potential in the opposite direction.

Purpose of the study. The development of scientific and methodological approach to assessing the potential of types of economic activities considering the environmental component.

Key findings. The formation of scientific and methodological support for assessing the potential of types of economic activities considering the environmental component requires the study of already existing mathematical modeling tools of this category. Thus, while carrying out a critical analysis of proposed approaches to assessing the potential $[10,11,12]$, it should be noted that, in parallel with the use of sufficiently powerful mathematical tools, in view of the priority of indicators of the attribute space, the use of a convolution of comprehensive directions of the characteristics of the research object in a generalizing, the failure to take account of economic nature of the potential, that is, a certain comparison of actual achieved level and the optimal reference level remains one of the problematic aspects.

The nature of the proposed method is to assess the potential of types of economic activities given the environmental component based on the deviation of normalized indicators of attribute space from the values of the "reference" level. So, following quasi-distances, a quantitative assessment of the potential of each type of economic activity is made, considering the environmental component, which makes it possible to establish an unachieved level in comparison with possible $100 \%$.

Turning to the adaptation of taxonometric method that satisfies all the above conditions, to assess the potential of economic activities subject to the environmental component, let's consider the following 
sequence of its formalization $[14,16]$ :

1. Formation of a set of indicators of attribute space, reflecting the potential of types of economic activities. To visualize this process, it is proposed to build a table layout that characterizes the values of indicators of attribute space, constructed on the basis of statistical reporting in the context of each type of economic activity.

2. Calculation of matrix values of indicators of the attribute space, reflecting the potential of types of economic activities considering the environmental component. This matrix acts as a concentrated expression of information describing different types of economic activity in the context of economic, social and environmental components.

3. Carrying out the normalization (bringing into comparable form) defined in points 1 and 2 of the indicator system of attribute space, which implies their transformation into a comparable form.

4. Formation of "reference" values characterizing economic, social and environmental components of types of economic activities.

5. Calculation of quasi-distances based on comparison of normalized indices of attribute space, characterizing the potential of types of economic activities, considering the environmental component with similar values of "reference" level.

To visualize the calculation procedure of taxonomic methods for assessing the potential of types of economic activities considering the environmental component, authors will perform the mathematical formalization of the calculation stages for solving the assigned task of economic and mathematical modeling.

At the first stage the identification of indicators of the attribute space characterizing the potential of types of economic activities considering the environmental component takes place. The indicators represented in Table 1 become the input informative base for constructing a given set of coefficients.

Table 1

Indicators characterizing the potential of types of economic activities, considering the environmental component in 2015

\begin{tabular}{|l|l|l|l|l|l|l|}
\hline \multirow{2}{*}{ Types of economic activity } & \multicolumn{2}{l}{ Economic component } & \multicolumn{2}{l}{ Social component } & \multicolumn{2}{l|}{$\begin{array}{l}\text { Environmental } \\
\text { component }\end{array}$} \\
\cline { 2 - 8 } & EC1 & EC2 & SC1 & SC2 & EnC1 & EnC2 \\
\hline Agriculture, forestry and fishery & 558788 & 27900 & 1.2 & 19.7 & 77.7 & 8736.8 \\
\hline Mineral industry and quarry development & 186194 & 17246.3 & 0.2 & 6.3 & 460.9 & 232642.4 \\
\hline Process industry & 1206047 & 44563.1 & 5.1 & 73.7 & 941.4 & 56506.3 \\
\hline $\begin{array}{l}\text { Supply of electricity, gas, steam and } \\
\text { conditioned air }\end{array}$ & 176768 & 21039.9 & 22.3 & 385.1 & 1174.3 & 6597.5 \\
\hline $\begin{array}{l}\text { Water supply; drain system, waste } \\
\text { management }\end{array}$ & 26982 & 1318.7 & 2.4 & 40.8 & 9 & 594.2 \\
\hline Building industry & 188595 & 40931.5 & 1 & 12.2 & 3.4 & 89.9 \\
\hline $\begin{array}{l}\text { Wholesale and retail trade; repair of } \\
\text { vehicles and motorcycles }\end{array}$ & 549163 & 18152.4 & 4.1 & 71.4 & 4.82 & 31.42 \\
\hline $\begin{array}{l}\text { Transport, warehousing, postal and } \\
\text { courier activities }\end{array}$ & 295634 & 16278 & 2.8 & 19.9 & 72.32 & 471.24 \\
\hline $\begin{array}{l}\text { Temporary accommodation and } \\
\text { arrangements for feeding }\end{array}$ & 25458 & 970 & 0.8 & 3.3 & 24.11 & 157.08 \\
\hline Information and telecommunications & 142223 & 21848.4 & 0.3 & 3.6 & 4.02 & 26.18 \\
\hline Financial and insurance activities & 107764 & 6223.7 & 0.2 & 4.2 & 2.41 & 15.71 \\
\hline Real estate & 176078 & 8797.6 & 0.4 & 4.2 & 1.61 & 10.47 \\
\hline $\begin{array}{l}\text { Professional, scientific and technical } \\
\text { activities }\end{array}$ & 107124 & 3805.3 & 0.6 & 7.8 & 0.80 & 5.24 \\
\hline $\begin{array}{l}\text { Activities in administrative and support } \\
\text { services }\end{array}$ & 43370 & 5677.4 & 1.1 & 8.1 & 6.43 & 41.89 \\
\hline $\begin{array}{l}\text { Public administration and defense; } \\
\text { compulsory social insurance }\end{array}$ & 147578 & 12547.5 & 2.7 & 26.9 & 33.75 & 219.91 \\
\hline Education & 119928 & 1176.4 & 1.4 & 27.2 & 0.96 & 6.28 \\
\hline Health care and social assistance & 88636 & 1550.2 & 2.1 & 19.3 & 2.25 & 14.66 \\
\hline Arts, sports, entertainment and recreation & 20436 & 921.4 & 0.3 & 2.8 & 3.21 & 20.94 \\
\hline Providing other services & 22475 & 206.5 & 0.4 & 5.3 & 4.02 & 26.18 \\
\hline
\end{tabular}


Notes: EC1 - The output of products and services in actual prices; mln. UAH; EC2 - Capital investments (used) in actual prices, mln.UAH; SC1 - Employers' need for workers, ths. people; SC2 - Work of registered unemployed, ths. people; EnC1 - Air pollutant emissions by stationary sources of pollution, ths. tons; EnC» - Formation of waste of I-IV hazard classes, ths. tons.

Continuing the formalization of a given taxon-metrical approach to assessing the potential of types of economic activities and considering the environmental component (the second stage), it is proposed to present the totality of considered indicators of the attribute space in a matrix form (equation 1).

$$
K=\left(\begin{array}{ccccc}
k_{11} & \ldots & k_{1 j} & \ldots & k_{1 n} \\
\ldots & \ldots & \ldots & \ldots & \ldots \\
k_{i 1} & \ldots & k_{i j} & \ldots & k_{i n} \\
\ldots & \ldots & \ldots & \ldots & \ldots \\
k_{m 1} & \ldots & k_{m j} & \ldots & k_{m n}
\end{array}\right)=\left(\begin{array}{cccccc}
k_{11} & k_{12} & k_{13} & k_{14} & k_{15} & k_{16} \\
k_{21} & k_{22} & k_{23} & k_{24} & k_{25} & k_{26} \\
k_{31} & k_{32} & k_{33} & k_{34} & k_{35} & k_{36} \\
k_{41} & k_{42} & k_{43} & k_{44} & k_{45} & k_{46} \\
k_{51} & k_{52} & k_{53} & k_{54} & k_{55} & k_{56}
\end{array}\right)
$$

where $\mathrm{K}$ - the matrix of indices of attribute space characterizing the potential of types of economic activities considering the environmental component;

$i=1 \div m-$ number of corresponding type of economic activity;

$j=1 \div n$ - number of corresponding indicator of attribute space;

$\mathrm{k}_{\mathrm{ij}}$ - the $\mathrm{j}$-th indicator evaluating the potential of the $\mathrm{i}$-th type of economic activity.

This approach to the presentation of incoming statistical data on the assessment of the potential of types of economic activities taking into account the environmental component allows both to concentrate and to visualize the informative base of the model and simplify the calculation procedure based on matrix operations.

At the third stage of implementation of taxonomic approach to definition the potential of types of economic activities considering the environmental component. It is advisable to bring the indicators of attributive space into a comparable form (equation 2):

$$
L=\left(\begin{array}{ccccc}
l_{11} & \ldots & l_{1 j} & \ldots & l_{1 n} \\
\ldots & \ldots & \ldots & \ldots & \ldots \\
l_{i 1} & \ldots & l_{i j} & \ldots & l_{i n} \\
\ldots & \ldots & \ldots & \ldots & \ldots \\
l_{m 1} & \ldots & l_{m j} & \ldots & l_{m n}
\end{array}\right)=\left(\begin{array}{cccccc}
l_{11} & l_{12} & l_{13} & l_{14} & l_{15} & l_{16} \\
l_{21} & l_{22} & l_{23} & l_{24} & l_{25} & l_{26} \\
l_{31} & l_{32} & l_{33} & l_{34} & l_{35} & l_{36} \\
l_{41} & l_{42} & l_{43} & l_{44} & l_{45} & l_{46} \\
l_{51} & l_{52} & l_{53} & l_{54} & l_{55} & l_{56}
\end{array}\right),
$$

that is, normalizing indicators to a comparable form, which is proposed to be carried out with the help of equations:

$$
\begin{aligned}
& l_{i j}=\left|\frac{k_{i j}-\overline{k_{i}}}{\sigma_{i}}\right| \\
& \overline{k_{i}}=\frac{1}{m} \sum_{j=1}^{n} k_{i j}, \sigma_{i}=\frac{1}{m} \sum_{j=1}^{n}\left(k_{i j}-\overline{k_{i}}\right)^{2},
\end{aligned}
$$

where $\mathrm{L}$ - the matrix of normalized indicators of attribute space characterizing the potential of types of economic activities considering the environmental component;

$l_{i j}$ - normalized $\mathrm{j}$-th indicator of evaluation of potential of the i-th type of economic activity.

$\overline{k_{i}}$ - the average value of the $\mathrm{j}$-th indicator for the totality of considered types of economic activities;

$\sigma_{i}-$ standard deviation of the $\mathrm{j}$-th index.

The need for the normalization of indicators of attribute space is due to the heterogeneity of forms of 
expression and the units of measurement in which they are represented.

At the fourth stage the calculation of "reference" values of indicators of attribute space, from the point of view of assessment of potential of types of economic activity considering the environmental component which is proposed to present as the matrix $\left(\begin{array}{ccccc}l_{11 e t} & \ldots & l_{1 j e t} & \ldots & l_{1 \text { net }} \\ \ldots & \ldots & \ldots & \ldots & \ldots \\ l_{\text {ilet }} & \ldots & l_{\text {ijet }} & \ldots & l_{\text {inet }} \\ \ldots & \ldots & \ldots & \ldots & \ldots \\ l_{\text {mlet }} & \ldots & l_{\text {mjet }} & \ldots & l_{\text {mnet }}\end{array}\right)$, where $l_{\text {ijet }}$ - normalized j-th reference indicator is performed.

The determination of the reference normalized value of the $\mathrm{j}$-th indicator of attribute space for the whole set of considered types of economic activity (maximum or minimum value depending on the direction of the impact on the outcome). Thus, the "reference" value of a corresponding indicator of attribute space is calculated as a minimum value, if an increase in this indicator leads to a loss of a certain level of potential, and the maximum value - otherwise. The maximum value for the model under consideration is selected for indicators characterizing the economic and social components of the potential.

4.2. Calculations of normalized "reference" values of indicators of attribute space are made by adjusting the optimal normalized value of the $j$-th indicator of potential of types of economic activities by the magnitude of standard deviation (equation 4), defined in clause 4.1:

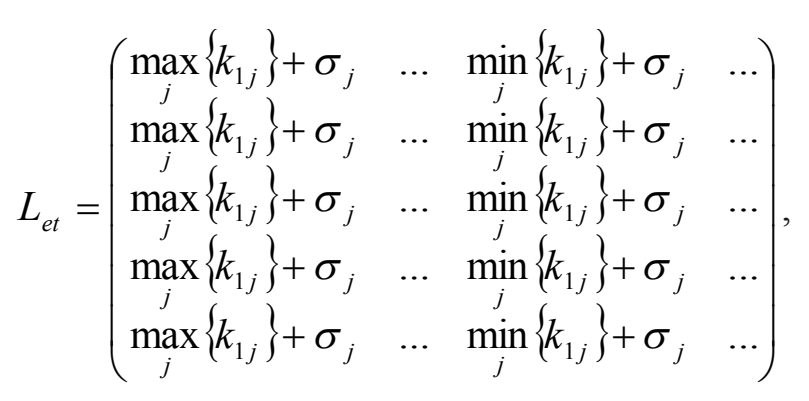

where $L_{e t}$ - the matrix of normalized "reference" values of indicators of the attribute space;

$\max _{j}\left\{k_{1 j}\right\}$ (accordingly $\min _{j}\left\{k_{1 j}\right\}$ ) - the determination of maximum (respectively, minimum) normalized value of the $j$-th indicator, depending on the direction of their influence on the outcome.

The basis for adjusting the reference values of indicators of attribute space by the average deviation is the assumption of the impossibility to achieve the "reference". Considering this fact, it can be noted that the "reference" is the value larger than the optimal normalized value of the $\mathrm{j}$-th indicator of attribute space. That is why, in our case, it is advisable to use the standard deviation as the correction coefficient, which characterizes the remoteness of the average value of the indicator from individual levels.

This stage is the basis of taxonomic approach to assessing the potential of types of economic activities taking into account the environmental component, since the "reference" level from the point of view of the potential provides an opportunity to form a tactics and development strategy, bringing the attribute space values to the reference value.

The fifth stage of scientific and methodological approach to the assessment of potential of types of economic activities considering the environmental component provides the calculation of quasi-distances between the i-th and "reference" levels based on the following equation:

$$
K V_{i}=\sum_{j=1}^{n-2}\left(l_{i j}-l_{i j e t}\right)^{2}-\sum_{j=n-1}^{n}\left(l_{i j}-l_{i j e t}\right)^{2},
$$

where $K V_{i}$ - quasi-distance between the i-th and "reference" levels. 
Table 4

Normalized indicators (the first line for each type of economic activity) and quasi-distances (the second line for each type of economic activity), which characterize the potential of types of economic activities taking into account the environmental component

\begin{tabular}{|c|c|c|c|c|c|c|}
\hline \multirow[t]{2}{*}{ Types of economic activity } & \multicolumn{2}{|c|}{ Economic component } & \multicolumn{2}{|c|}{ Social component } & \multicolumn{2}{|c|}{ Environmental component } \\
\hline & $\mathrm{EC} 1$ & $\mathrm{EC} 2$ & $\mathrm{SC} 1$ & $\mathrm{SC} 2$ & $\mathrm{EnC} 1$ & $\mathrm{EnC} 2$ \\
\hline $\begin{array}{l}\text { Agriculture, forestry and } \\
\text { fishery }\end{array}$ & 1.189 & 1.091 & 0.281 & 0.851 & 0.210 & 0.137 \\
\hline $\begin{array}{l}\text { Mineral industry and } \\
\text { quarry development }\end{array}$ & 9.179 & 3.271 & 20.593 & 14.680 & 0.539 & 0.735 \\
\hline Process industry & 0.121 & 0.299 & 0.482 & 0.438 & 0.920 & 4.009 \\
\hline $\begin{array}{l}\text { Supply of electricity, gas, } \\
\text { steam and conditioned air }\end{array}$ & 16.798 & 6.762 & 18.809 & 18.013 & 0.001 & 9.091 \\
\hline $\begin{array}{l}\text { Water supply; drain } \\
\text { system, waste management }\end{array}$ & 3.465 & 2.329 & 0.502 & 0.328 & 2.337 & 0.748 \\
\hline Building industry & 0.568 & 0.325 & 18.635 & 18.957 & 1.942 & 0.061 \\
\hline $\begin{array}{l}\text { Wholesale and retail trade; } \\
\text { repair of vehicles and } \\
\text { motorcycles }\end{array}$ & 0.154 & 0.581 & 3.967 & 3.866 & 3.024 & 0.176 \\
\hline $\begin{array}{l}\text { Transport, warehousing, } \\
\text { postal and courier } \\
\text { activities }\end{array}$ & 16.527 & 5.375 & 0.727 & 0.666 & 4.328 & 0.669 \\
\hline $\begin{array}{l}\text { Temporary } \\
\text { accommodation and } \\
\text { arrangements for feeding }\end{array}$ & 0.680 & 0.884 & 0.047 & 0.046 & 0.412 & 0.287 \\
\hline $\begin{array}{l}\text { Information and } \\
\text { telecommunications }\end{array}$ & 12.523 & 4.061 & 22.771 & 21.489 & 0.282 & 0.499 \\
\hline $\begin{array}{l}\text { Financial and insurance } \\
\text { activities }\end{array}$ & 0.112 & 2.059 & 0.322 & 0.371 & 0.429 & 0.297 \\
\hline Real estate & 16.867 & 0.706 & 20.230 & 18.587 & 0.265 & 0.486 \\
\hline $\begin{array}{l}\text { Professional, scientific and } \\
\text { technical activities }\end{array}$ & 1.156 & 0.367 & 0.301 & 0.302 & 0.425 & 0.298 \\
\hline $\begin{array}{l}\text { Activities in administrative } \\
\text { and support services }\end{array}$ & 9.385 & 6.416 & 20.411 & 19.185 & 0.269 & 0.485 \\
\hline $\begin{array}{l}\text { Public administration and } \\
\text { defense; compulsory social } \\
\text { insurance }\end{array}$ & 0.264 & 0.227 & 0.040 & 0.283 & 0.226 & 0.290 \\
\hline Education & 15.641 & 7.141 & 22.840 & 19.349 & 0.515 & 0.496 \\
\hline $\begin{array}{l}\text { Health care and social } \\
\text { assistance }\end{array}$ & 0.686 & 0.910 & 0.362 & 0.358 & 0.368 & 0.296 \\
\hline $\begin{array}{l}\text { Arts, sports, entertainment } \\
\text { and recreation }\end{array}$ & 12.485 & 3.958 & 19.870 & 18.695 & 0.332 & 0.488 \\
\hline Providing other services & 0.275 & 0.641 & 0.462 & 0.468 & 0.427 & 0.298 \\
\hline
\end{tabular}

Notes: EC1 - The output of products and services in actual prices; mln. UAH; EC2 - Capital investments (used) in actual prices, mln.UAH; SC1 - Employers' need for workers, ths. people; SC2 - Work of registered unemployed, ths. people; EnC1 - Air pollutant emissions by stationary sources of pollution, ths. tons; EnC» - Formation of waste of I-IV hazard classes, ths. tons.

The quasi-distances are calculated and presented in Table 4, and act as a quantitative characteristic, which shows the correspondence of the level of potential of economic activities considering the environmental component of the reference value.

Based on the data given in Table 2, it is fair to note that in Ukraine most of the economic activities are not realized even by half. Such types of economic activities as transport, warehousing, postal and courier activities, public administration and defense; compulsory social insurance have the potential opportunities for growth at a level of more than $63 \%$. If it can be argued on transport, that a significant part of the realization of its potential lies within the environmental component, namely the minimization of emissions into the atmosphere from motor vehicles, then the state administration and defense, its potential capacities accumulate within the economic and social component. 
Table 2

The potential of types of economic activities, taking into account the environmental component

\begin{tabular}{|l|r|}
\hline \multicolumn{1}{|c|}{ Types of economic activities } & Potential \\
\hline Agriculture, forestry and fishery & 46.45 \\
\hline Mineral industry and quarry development & 51.29 \\
\hline Process industry & 36.48 \\
\hline Supply of electricity, gas, steam and conditioned air & 18.30 \\
\hline Water supply; drain system, waste management & 60.06 \\
\hline Building industry & 55.64 \\
\hline Wholesale and retail trade; repair of vehicles and motorcycles & 54.64 \\
\hline Transport, warehousing, postal and courier activities & 63.96 \\
\hline Temporary accommodation and arrangements for feeding & 54.19 \\
\hline Information and telecommunications & 56.64 \\
\hline Financial and insurance activities & 56.15 \\
\hline Real estate & 59.35 \\
\hline Professional, scientific and technical activities & 56.37 \\
\hline Activities in administrative and support services & 56.24 \\
\hline Public administration and defense; compulsory social insurance & 66.06 \\
\hline Education & 59.26 \\
\hline Health care and social assistance & 59.05 \\
\hline Arts, sports, entertainment and recreation & 52.22 \\
\hline Providing other services & 52.47 \\
\hline
\end{tabular}

The lowest value of the potential, considering the environmental component, has a supply of electricity, gas, steam and conditioned air and makes $18.3 \%$. This is quite logical, since the supply of electricity and gas is relatively environmentally friendly but to it, even in Ukraine, conditions are set in terms of minimizing environmental risks. Assessing their opportunities within the economic and social components, it is fair to note that currently there are no vectors for the development of these types of economic activities. Power lines and gas pipelines cover almost all the necessary territory of Ukraine, and there are no investment resources for improvement in sufficient volume.

The potential for all other types of economic activity in Ukraine are in the range of values from $47 \%$ to $60 \%$ and is formed from all three of its components. So, there are more than enough opportunities for restructuring Ukraine's economy, each type of economic activity can act as an impulse and a leader in structural changes.

Conclusions. Thus, the development of the assessment of the level of potential of types of economic activities taking into account the environmental component, which, unlike the existing ones, is proposed to be viewed as a combination of three components (economic, social and environmental) through a transition to normalized indicators (weighing the deviation of a current level by average on the standard deviation) and their subsequent convolution to a single integral criterion - quasi-distances based on the deviation from the reference level, calculated by adjusting the maximum (for stimulants) and the minimum (for disincentives) values by the value of standard deviation, which allows to establish unachieved level as compared with possible $100 \%$.

Further researches will be aimed at increasing the factors that form the economic, social and environmental components, as well as studies of the dynamic changes in the potential of each type of economic activity and their comparison with the potential value without considering the environmental component.

\section{REFERENCES:}

1. Amosov, O.Yu. (2011) Otsenka Ustoychivogo Razvitiya Prognoziruemoy Problemy Aktivnogo Raznoobraziya. Problemy ekonomiky, NDTS Industrialnykh problem rozvytku NAN Ukrainy, № 3, P. 79 83.

2. Balatskiy, O. F. (2006) Ekonomicheskiy potentsial prav i proizvodstvennykh sistem. Monografiya. Sumy: Universitetskaya kniga, 972 p.

3. Varnalii, Z.S. (2005) Rehiony Ukrainy: problemy i priorytet sotsialno-ekonomichnoho rozvytku. Monohrafiia. Kyiv : Znannia Ukrainy, 498 p.

4. Voronkova, A.E. (2000) Strategicheskoye upravleniye konkurentosposobnym potentsialom predpriyatiya: diagnostika i organizatsiya, Lviv: VNU im. Dalia, 315 p.

5. Hrynov, A.V. (2003) Otsinka innovatsiinoho potentsialu pidpryiemstva. Problemy nauky. № 12, P. 
12-17.

6. Hrynova, V.M. (2009) Upravlinnia rozvytkom trudovoho potentsialu pidpryiemstva. Monohrafiia. Kharkiv: KHNEU, 256 p.

7. Dekhtiarenko H.V. (2013) Analiz metodychnykh pidkhodiv i metodiv otsinky trudovoho potentsialu pidpryiemstva. Upravlinnia rozvytkom, № 23 (163), P. 164-166. Access mode: http://irbisnbuv.gov.ua/cgi-bin/irbis_nbuv/cgiirbis_64.exe? Pdf.

8. Diblenko, V.I. (2012) Suchasni pidkhody shchodo otsiniuvannia trudovoho potentsialu pidpryiemstva. Visnyk KNUTD, № 6, P. 277-281.

9. Il'huk, O.O. (2012) Osoblyvosti vykorystannia i analiz trudovoho potentsialu pidpryiemstva sfery posluh. Naukovyi visnyk NLTU Ukrainy. Vypusk 22.14, P. 220-226.

10.Kaliuzhna, N.H. (2016) Model razvitiya potentsiala silovykh vedomstv: opisaniye i perspektivy. Marketing i menedzhment innovatsiy, № 2. Access mode: http://mmi.fem.sumdu.edu.ua/

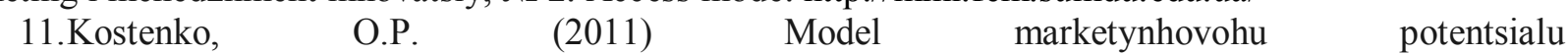
promyslovoho typu. Access mode: http://www.nbuv.gov.ua/old_jrn/Soc_Gum/Dtr_ep/2011_3/files/EC311_1 6.pdf

12.Kuzmenko, O.V. (2014) Ekonomiko-matematychne zabezpechennia funktsionuvanvannia perestrakhovoho rynku. Monohrafiia. Sumy, Universytetska knyha, 430 p.

13. Martyusheva, L.S. (2002) Innovatsiinyi potentsial pidpryiemstva yak obiekt ekonomichnoho doslidzhennia. Finansy Ukrainy, № 10, P. 61-66.

14.Melnyk, L.H., 2014, Trialectics of Systems Formation and Development. Actual Problems of Economics. № 10 (160). P. 34-39.

15.Melnyk, L.H., 2016, Tools and key factors of sustainable ("green") economy. Actual Problems of Economics. №4 (178). P. 30-36.

16. Musiienko, O.M. (2014) Suchasna praktyka reitinhovoho otsiniuvannia diialnosti bankiv na osnovi taksonometrychnoho metodu. Finansovoe Prostranstvo, № 1 (13), P. 121-127. P. 68-75.

17.Rossokha, V.V. (2005) Metodika otsifrovki potentsiala. Aktualni problemy ekonomiky. № 5 (47),

18.Samorodov, B.V. (2012) Porivnialnyi analiz matematychnykh osoblyvostei taksonometrychnoho metodu pry reitynhuvanni bankiv. Chasopys ekonomichnykh reform, № 1, P. 34-41.

19.Smirnova, G.A. (2001) Innovatsionnyy potentsial predpriyatiy, yego otsenka i metody realizatsii. Innovatsii, № 7 (44), P. 49-51.

20.Fedonin, O.S. (2003) Potentsial pidpryiemstva: formuvannia ta otsinka. Kyiv: KNEU, 316 p.

21.Khomiakov, V.I. (2007) Upravlinnia potentsialom pidpryiemstva. Kyiv: Kondor, 400 p.

УДК: 332.142 .6

Карінцева Олександра Іванівна, кандидат економічних наук, доцент, доцент кафедри економіки, підприємництва та бізнес-адміністрування. Сумський державний університет. Науковометодичний підхід до оцінювання потенціалу видів економічної діяльності 3 урахуванням екологічної складової. В статті розглянуто особливості побудови науково-методичного підходу до оцінювання потенціалу видів економічної діяльності. Кількісне вимірювання потенціалу видів економічної діяльності створює інформаційну основу для прийняття ефективних управлінських рішень на макрорівні 3 приводу інвестиційної спрямованості ресурсів та векторів державної підтримки економіки, а на мікрорівні рівні з приводу подальшої можливості розвитку бізнесу та стадії життєвого циклу компанії. Розрахований інтегральний показник враховує позитивний вплив, який кожний вид економічної діяльності здійснює на економічну та соціальну складову державного розвитку, а також деструктивний вплив на екологічну складову сталого розвитку країни. Практичний розрахунок потенціалу видів економічної діяльності в Україні засвідчив значний резерв до зростання даного показника за умови мінімізації завданої шкоди навколишньому середовищу. Потенціал для всіх інші видів економічної діяльності в Україні, знаходяться в проміжку значень від 47\% до 60\% та формується з усіх трьох його складових. Отже, можливостей для реструктуризації економіки України більше ніж достатньо, кожен вид економічної діяльності спроможний виступити імпульсом та лідером структурних змін.

Ключові слова: потенціал, види економічної діяльності, еталон, екологічна складова, квазівідстані. 
UDC: 332.142 .6

Karintseva Oleksandra. PhD in Economics, Associate Professor, Department of Economics, Entrepreneurship and Business-Administration. Sumy State University. Scientific and methodological approach to the evaluation of the potential of economic activities types. The article investigates the features of the construction of scientific and methodical approach to the potential assessment of economic activities. Calculated integrated index takes into account the positive impact that each type of economic activity has on economic and social components of national development, as well as a destructive influence of environmental component on sustainable development of the country. The practical calculation of potential of economic activities in Ukraine showed a significant reserve to the increase of this indicator provided to minimize the damage caused to the environment.

Keywords: potential, types of economic activities, reference, environmental component, quasidistances.
УДК: 332.142 .6

Каринцева Александра Ивановна, кандидат экономических наук, доцент, доцент кафедры экономики, предпринимательства и бизнесадминистрирования. Сумский государственный университет. Научно-методический подход к оценке потенциала видов экономической деятельности с учетом экологической составляющей. В статье рассмотрены особенности построения научно-методического подхода к оценке потенциала видов экономической деятельности. Рассчитанный интегральный показатель учитывает положительное влияние, которое каждый вид экономической деятельности осуществляет на экономическую и социальную составляющую государственного развития, а так же деструктивное влияние на экологическую составляющую устойчивого развития страны. Практический расчет потенциала видов экономической деятельности в Украине показал значительный резерв к росту данного показателя при условии минимизации ущерба окружающей среде.

Ключевые слова: потенциал, виды экономической деятельности, эталон, экологическая составляющая, квазирасстояния. 